\title{
PKM PALAPA (Pembuatan Aplikasi Laporan Perkembangan Anak) Kelompok A Pada TK An Shal Kecamatan Kamal Kabupaten Bangkalan
}

\author{
Rica Wijayanti ${ }^{1}$ \\ ${ }^{1}$ Program Studi Pendidikan Matematika, STKIP PGRI Bangkalan-Jalan Soekarno \\ E-mail: ricawijayanti@stkippgri-bkl.ac.id. No. HP 081217230875
}

\begin{abstract}
ABSTRAK
Taman kanak-kanak adalah salah satu jenjang pendidikan yang mulai digalakkan oleh pemerintah sebelum menempuh jenjang Sekolah Dasar. Berdasarkan observasi awal yang dilakukan oleh pelaksana pengabdian di TK AN-SHAL tampak bahwa beberapa anak telah berkembang sesuai tahap perkembangan anak usia mereka, namun beberapa anak justru tertinggal jauh. Hal ini yang menjadi permasalahan di sekolah tersebut. Anak yang perkembangannya masih di bawah rata-rata memiliki kecendeungan malas ketika diberi tugas baik di sekolah maupun di rumah. Salah satu usaha yang dilakukan oleh guru di TK AN-SHAL adalah membuat surat penggilan kepada para orang tua yang anaknya mengalami permasalahan. Namun, usaha tersebut seolah-olah menjadi sisa-sia karena kebanyakan orang tua mereka tidak bisa hadir dan yang hadir adalah para pengasuh yang bertugas mengantar dan menjemput anak-anak tersebut. Kesulitan ini sangat dirasakan oleh guru-guru karena kebanyakan orang tua dari siswa mereka sibuk untuk bekerja. Akibatnya, permasalahan anak yang malas mengerjakan tugas terus terjadi. Solusi yang diberikan dalam program pengabian masyarakat ini adalah dibuatnya sebuah aplikasi laporan perkembangan anak berbasis android. Metode yang digunakan adalah menggunakan metode pengembangan. Pembuatan aplikasi ini dikembangkan dari laporan perkembangan anak yang berbentuk manual menjadi sebuah aplikasi dengan bantuan aplikasi android developer kit dan java SE. Hasil dari pengabdian ini menunjukkan bahwa aplikasi yang dibuat mendapatkan respon posititf dari pengguna yaitu para guru dan para orang tua siswa. Dari penyebaran angket yang diberikan kepada pengguna sebanyak 95\% menyatakan aplikasi ini sangat efektif digunakan dan dapat membantu pengguna untuk mengontrol perkembangan anak.
\end{abstract}

Kata kunci : PKM; PALAPA; perkembangan anak

\section{ABSTRACT}

Kindergarten is one of the levels of education that began to be promoted by the government before going through the elementary school level. Based on preliminary observations made by service providers at the AN-SHAL Kindergarten, it appears that some children have developed according to the stage of development of their children, but some children are far behind. This is a problem at the school. Children whose development is still below average have lazy tendencies when given assignments both at school and at home. One of the efforts made by the teacher at the AN-SHAL Kindergarten was to make a letter to parents whose children had problems. However, the effort seemed to be a waste because most of their parents could not attend and those present were the caregivers who were in charge of delivering and picking up the children. This difficulty is felt by teachers because most parents of their students are busy working. As a result, the problem of children who are lazy to do tasks continues. The solution given in this community service program is to make an android child development report application. The method used is using the development method. The making of this application was developed from a report on child 
JAST : Jurnal Aplikasi Sains dan Teknologi, 2 (2), 2018, page 74-80

Tersedia online di https://jurnal.unitri.ac.id/index.php/jast

ISSN 2548-7981 (Online)

development in the form of a manual into an application with the help of an android developer kit application and java SE. The results of this service show that the applications made get positive responses from users, namely the teachers and parents of students. From the distribution of questionnaires given to users as much as $95 \%$ said this application is very effective to use and can help users to control the development of children.

Keywords : PKM; PALAPA; child development

\section{PENDAHULUAN}

Taman kanak-kanak adalah salah satu jenjang pendidikan yang mulai digalakkan oleh pemerintah sebelum menempuh jenjang Sekolah Dasar. Tujuan dari dibentuknya taman kanak-kanak adalah untuk mematangkan perkembangan anak. Berdasarkan tahap perkembangan menurut Piaget (Ahmad, 2011), usia anak pada masa taman kanak-kanak berada pada tahap pra operasional. Pada tahap perkembangan ini anak seharusnya sudah memiliki beragam jenis kemampuan baik dari segi kemampuan berbahasa, berhitung, mewarnai dan mengingat. Semua perkembangan anak tersebut sangat penting untuk diketahui oleh orang tua.

Salah satu taman kanak-kanak yang berada di Kecamatan Kamal adalah taman kanak-kanak An-Shal. Tanamn kanakkanak ini berdiri dibawah naungan sebuah yayasan keluarga besar Bani Kadir. Taman kanak-kanak AN-SHAL berdiri dari tahun 2015 dan memiliki ijin dari Diknas Bangkalan tahun 2106. TK ini terdiri dari kelompok bermain, TK B dan TK A. Taman kanak-kanak ini masuk selama 6 hari yaitu hari Senin sampai hari Sabtu dengan jam pelaksanaan pukul 07.00-09.30. Jumlah peserta kelompok A pada sekolah ini adalah 18 orang siswa.
Berikut ini adalah potret dari proses pembelajaran di TK AN-SHAL.

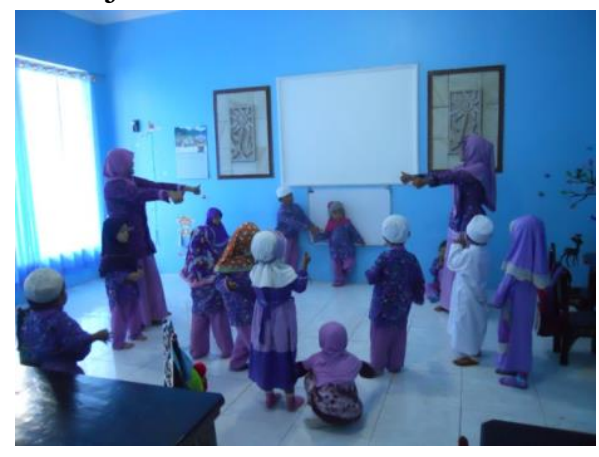

Gambar 1. Suasana belajar TK An-Shal

Berdasarkan observasi awal yang dilakukan oleh pelaksana pengabdian, di sekolah tersebut tampak bahwa beberapa anak telah berkembang sesuai tahap perkembangan anak usia mereka, namun beberapa anak justru tertinggal jauh. Hal ini yang menjadi permasalahan di sekolah tersebut. Anak yang perkembangannya masih di bawah rata-rata memiliki kecendeungan malas ketika diberi tugas baik di sekolah maupun di rumah. Sebenarnya pihak guru-guru sudah berusaha untuk berkomunikasi dengan orang tua anak tersebut, namun hasilnya belum signifikan. Salah satu usaha yang dilakukan oleh guru di TK AN-SHAL adalah membuat surat penggilan kepada para orang tua yang anaknya mengalami permasalahan. Namun, usaha tersebut seolah-olah menjadi sisa-sia karena kebanyakan orang tua mereka tidak bisa hadir dan yang hadir adalah para pengasuh 
yang bertugas mengantar dan menjemput anak-anak tersebut.

Kesulitan ini sangat dirasakan oleh guru-guru karena kebanyakan orang tua dari siswa mereka sibuk untuk bekerja. Akibatnya, permasalahan anak yang malas mengerjakan tugas terus terjadi. Para orang tua hanya dapat hadir ketika mereka mengambil raport saja di akhir semester. Permasalahan yang sangat memberikan pengaruh besar terhadap kemajuan anak didik ini harus mendapatkan penanganan khusu. Para guru berharap ada program yang bisa membantu mereka untuk berkomunikasi dengan orag tua siswa tentang perkembangan anak mereka setiap saat, sehingga para orang tua dapat lebih cepat memberikan penanganan khusus.

Berdasarkan analisis situasi yang telah dilakukan oleh pelaksana pengabdian, maka terdapat tiga permasalahan yang menjadi prioritas untuk diselesaikan dalam program kemitraan masyarakat ini. Adapun permaslahan tersebut yaitu sebagai berikut,

a. Kesulitan mitra untuk bertemu dan mengumpulkan orang tua siswa guna membicarakan perkembangan siswa tersebut ketika di sekolah. Hal ini dikarenakan banyak orang tua siswa yang bekerja, sehingga jika diadakan pertemuan banyak yang tidak datang kecuali di akhir semester.

b. Belum adanya program yang dimiliki mitra untuk membaca data perkembangan siswanya secara cepat, sehingga mitra lama dalam mengambil suatu tindakan.

c. Perkembangan teknologi yang semakin pesat, sehingga orang tua siswa menginginkan mitra dapat memberikan informasi dengan cepat tentang kemajuan anak di TK AN-SHAL

\section{METODE KEGIATAN}

Berdasarkan hasil pemaparan di atas tentang permasalahan yang dialami oleh mitra, maka dalam pengabdian ini akan diberikan beberapa metode sebagai solusi dari permasalahan diantaranya yaitu sebagai berikut.

\section{- Pendidikan Masyarakat}

Sebelum membuatkan sebuah aplikasi yang berisi laporan perkembangan anak, pengabdi akan mengumpulkan para orang tua siswa untuk menanyakan keinginan orang tua pada pihak sekolah tentang bentuk laporan perkembangan anak mereka selama berada di sekolah. Segala bentuk keinginan orang tua siswa akan dicatat dan dijadikan masukan sebagai bahan pembuatan aplikasi

- Konsultasi

Setelah mengadakan kegiatan pertemuan dengan orang tua siswa pengabdi juga mengadakan konsultasi dengan pihak sekolah yaitu kepala sekolah dan guru selaku pembuat laporan perkembangan anak. Pada kegiatan ini pengabdi juga meminta data tentang segala bentuk laporan perkembangan anak kelompok A di TK An-Shal.

\section{○ Difusi Ipteks}

Pengabdi membuat sebuah aplikasi yang berisi laporan perkembangan anak kelompok A TK An-Shal. Pembuatan aplikasi ini dikembangkan dari laporan perkembangan anak yang berbentuk manual menjadi sebuah aplikasi dengan bantuan aplikasi android developer kit 
dan java SE. Aplikasi ini akan digunakan sebagai bentuk komunikasi anatar pihak sekolah dan pihak orang tua siswa.

- Pelatihan

Aplikasi yang sudah jadi diberi nama aplikasi PALAPA. Sebelum mengadakan simulasi tentang penggunaan aplikasi kepada para orang tua siswa, pengabdi akan mengadakan pelatihan kepada pihak sekolah yaitu kepala sekolah dan guru. Pelatihan ini berguna agar pihak sekolah mengetahui cara memasukkan laporan perkembangan anak ke dalam aplikasi PALAPA.

- Simulasi Ipteks

Setelah diadakan pelatihan kepada pihak sekolah, aplikasi PALAPA akan dikenalkan dengan cara simulasi kepada para orang tua murid yang akan menjadi pengguna dari aplikasi PALAPA. Penggunaan aplikasi ini akan dipantau oleh pengabdi masyarakat sehingga jika ada kendala yang dihadapi oleh pengguna maka akan lebih cepat teratasi.

\section{KARYA UTAMA}

Karya utama yang dihasilkan oleh pengabdi pada program pengabdian kepada masyarakat ini adalah sebuah aplikasi android. Aplikasi ini berisikan tentang laporan perkembangan anak kelompok A pada TK An-Shal di Kecamatan Kamal Kabupaten Bangkalan. Aplikasi yang dihasilkan akan diberi nama Aplikasi PALAPA. Dalam pembuatan aplikasi ini pengabdi menggunakan bantuan aplikasi android developer kit dan java SE.
Aplikasi PALAPA akan memuat tentang enam jenis perkembangan anak yaitu nilai agama dan moral, motorik, kognitif, sosial emosional, bahas, dan seni. Setiap perkembangan anak yang ada pada aplikasi akan dilengkapi dengan komentar guru dan tindakan orang tua sebagai umpan balik dari setiap perkembangan anak. Berikut ini gambaran dari aplikasi PALAPA yang dibuat.

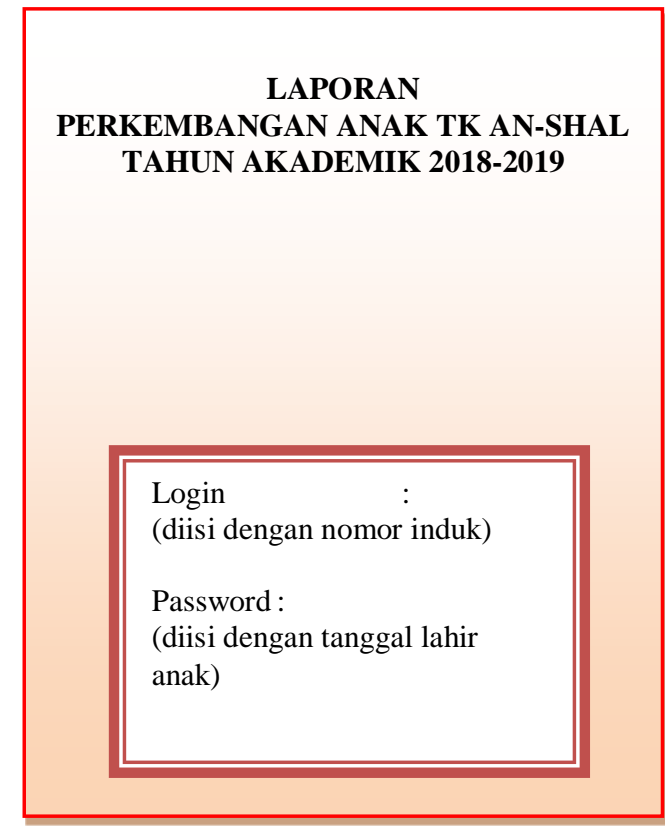

Gambar 1. Tampilan Depan Aplikasi PALAPA

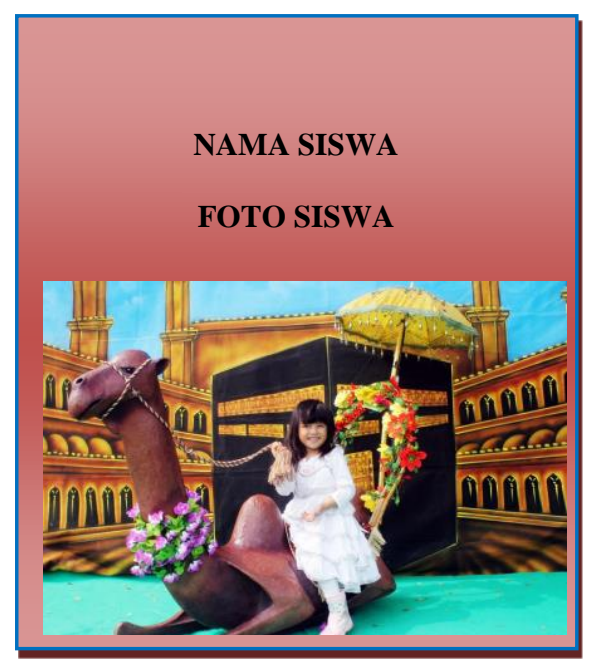

Gambar 2. Tampilan Kedua Aplikasi PALAPA 


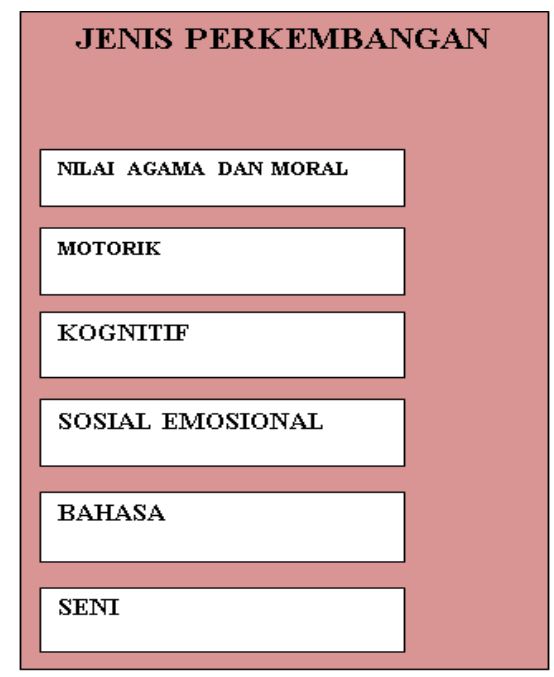

Gambar 3. Tampilan Ketiga Aplikasi PALAPA

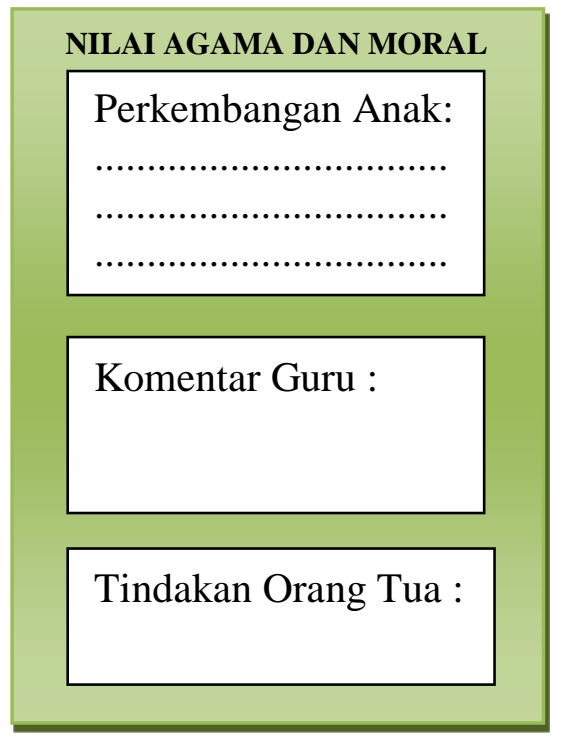

Gambar 4. Tampilan Isi Aplikasi PALAPA

\section{ULASAN KARYA}

Keunggulan aplikasi PALAPA ini adalah orang tua siswa selaku pengguna tidak perlu datang ke sekolah untuk mengetahui perkembangan anak mereka selama di sekolah. Selain itu aplikasi ini dirancang sederhana sehingga semua kalangan dapat menggunakannnya tanpa harus memiliki keahlian khusus. Aplikasi ini dapat diinstall di handphone android tipe apa saja.
Selain memiliki keunggulan, aplikasi PALAPA juga memiliki kelemahan yaitu pihak sekolah harus selalu mengupdate isi aplikasi setiap harinya sehingga informasi yang berada di dalam aplikasi PALAPA terus berganti dan hal ini membutuhkan waktu khusus untuk pihak sekolah. Selain itu, orang tua yang ingin menggunakan aplikasi ini harus memiliki handphone android sehingga aplikasi PALAPA dapat diinstal di handphone orang tua siswa.

Dalam proses pembuatan aplikasi PALAPA ini cukup mudah. Namun, penuh tantangan terutama ketika harus menghubungkan antara data manual yang diperoleh dari sekolah ke item yang terdapat pada aplikasi PALAPA. Aplikasi ini dapat dikembangkan lebih lanjut pada jenjang pendidikan yang lebih tinggi tidak hanya pada taman kanak-kanak melainkan juga pada jenjang pendidikan yang lebih tinggi

\section{DAMPAK DAN MANFAAT KEGIATAN}

Pembuatan aplikasi PALAPA memberikan dampak yang cukup besar bagi mitra program pengabdian masyarakat yaitu TK An-Shal. Setelah dibuatnya aplikasi ini terjadi peningkatan perkembangan anak di sekolah tersebut. Anak yang awalnya kurang semangat dan malas belajar menjadi anak yang rajin karena orang tua juga memberikan dorongan pada anak mereka untuk belajar.

Selain itu, orang tua siswa yang bekerja di kantor dapat terus memantau perkembangan anak mereka disela-sela kegiatan di kantor tanpa harus datang langsung di sekolah. Hubungan sosial juga 
mulai terjalin antara pihak sekolah dan pihak orang tua siswa sehingga segala bentuk permaslahan anak yang terjadi di sekolah khususnya tentang perkembangan anak dapat segera diatasi oleh orang tua siswa ketika berada di rumah.

\section{KESIMPULAN}

Masalah yang dialami mitra yaitu tentang sulitnya bertemu dengan orang tua siswa untuk memberikan informasi tentang masalah perkembangan anak dpat teratasi setelah diadakan program pengabdian masyarakat yang membuat aplikasi PALAPA. Aplikasi ini sudah terbukti menjadi salah satu alternatif paling tepat untuk mengatasi sulitnya berkomunikasi karena adanya keterbatasan ruang dan waktu. Aplikasi yang dikembangkan ini sangat cocok digunakan di era industri 4.0 yang identik dengan teknologi canggih, cepat dan tepat guna.

Berdasarkan hasil dari program pengabdian masyarakat ini, maka pengabdi menyarakan untuk diadakan pengembangan lebih lanjut tentang pembuatan aplikasi PALAPA. Pengembangan dapat dilakukan oleh pengabdi yang lain dengan cara membuat aplikasi serupa untuk jenjang pendidikanyang tingkatannya lebih tinggi atau untuk bidang di luar dunia pendidikan,

\section{PENGHARGAAN}

Pada kesempatan ini pengabdi masyarakat mengucapkan terima kasih kepada Lembaga Penelitian dan Pengabdian Masyarakat (LPPM) STKIP PGRI Bangkalan yang telah memberikan dana hibah mandiri untuk program pengabdian kepada masyarakat dengan judul PKM PALAPA (Pembuatan Aplikasi Laporan Perkembangan Anak). Selain itu kami juga mengucapkan terima kasih kepada pihak-pihak yang terlibat dalam pengabdia ini yaitu kepala sekolah, guru-guru serta orang tua siswa TK AnShal dan dua mahasiswa program studi matematika yang ikut membantu selama proses pengabdian masyarakat dilakukan.

\section{DAFTAR PUSTAKA}

[1] Ahmad, Susanto. (2011). Perkembangan Anak Usia Dini.. Jakarta: Kencana

[2] Anita Yus. (2005). Penilaian Perkembangan Belajar Anak Taman Kanak-kanak. Jakarta: Departemen Pendidikan Nasional Direktorat Jenderal PerguruanTinggi Direktorat Pembinaan Pendidikan Tenaga Kependidikan danKetenagaan Perguruan Tinggi.

[3] Departemen Pendidikan Nasional. (2006). Pedoman Pembelajaran di Taman Kanak-kanak. Jakarta: Departemen Pendidikan Nasional Direktorat Jenderal Manajemen Pendidikan Dasar dan Menengah Direktorat Pembinaan Taman Kanakkanak dan Sekolah Dasar.

[4] Desmita. (2007). Psikologi Perkembangan. Bandung: PT Remaja Rosdakarya

[5] Harun Rasyid, Mansyur, dan Suratno. (2009). Asesmen Perkembangan Anak UsiaDini. Yogyakarta: Multi Pressindo. 
[6] Sofia Hartati. (2005). Perkembangan Belajar pada Anak Usia Dini. Jakarta: Departemen Pendidikan Nasional Direktorat Jenderal Perguruan Tinggi
Direktorat Pembinaan Pendidikan

Tenaga Kependidikan dan

Ketenagaan Perguruan Tinggi. 